\title{
Natural (A)theologies in Ancient Israel: Descriptive PERSPECTIVES FROM PHILOSOPHY OF RELIGION
}

Author:

Jacobus W. Gericke

\section{Affiliation:}

${ }^{1}$ School of Basic Sciences, North-West University,

Vaal Triangle Campus,

South Africa

\section{Correspondence to:}

Jacobus Gericke

email:

21609268@nwu.ac.za

\section{Postal address:}

School of Basic Sciences,

Faculty of Humanities,

North-West University, Vaal

Triangle Campus, PO Box

1174, Vanderbijlpark 1900,

South Africa

\section{Keywords:}

arguments for the existence of God; atheism; atheology; biblical theology; Natural theology

\section{Dates:}

Received: 26 May 2010

Accepted: 18 Aug. 2010

Published: 10 Nov. 2010

How to cite this article: Gericke, J.W., 2010,

'Natural (a)theologies in Ancient Israel: Descriptive perspectives from philosophy of religion', Verbum et Ecclesia 31(1), Art. \#401, 6 pages. DOI: 10.4102/ ve.v31i1.401

\section{This article is available} at: http://www.ve.org.za

(C) 2010. The Authors. Licensee: OpenJournals Publishing. This work is licensed under the Creative Commons Attribution License.

\begin{abstract}
According to popular consensus, the ancient Israelites shunned natural theology and belief in Yahweh was based on revelation and not reason. In relatively recent times, this view has come under increasing pressure as the presence of natural theology in the Hebrew Bible has turned into a topic of sporadic interest. In this article, a contribution to this discussion is made by way of placing the topic in its proper framework within the philosophy of religion. In doing so, it provides a descriptive introduction to what will for the foreseen future remain a controversial issue.
\end{abstract}

\section{INTRODUCTION}

In biblical theology, it is commonplace to suggest that the Hebrew Bible does not attempt to prove the existence of Yhwh (Köhler 1957:19; Jacob 1958:37; Preuss 1995:139, et al.). All that is remarked on the subject involves pointing out that only fools doubt it and adding that the nature of this doubt was practical, not theoretical (e.g. Ps 10:4; 14:1; 53:1, Zeph 12). For many biblical theologies and commentaries, what can be said on the matter boils down to the following summary of Rowley (1956):

The thought of the Old Testament is centred in God. Yet it is nowhere attempted to prove God exists. For the God of the Old Testament is the God of experience and not of speculation. It is not because some postulate of thought led men to think of a first cause that they turned to the thought of God. They no more questioned his being than they questioned the reality of the world around themselves. The philosopher may raise doubts about the reality of all things, but the plain man is content to base his belief in the reality of the world on his experience, however illusionary the philosopher may tell him it is. So the Hebrew was content to base his belief in the existence of God on what seemed to him to be his experience of God, granted to himself or to his people, and especially on the experience of God given to the nation in the great moments of its history ... He (God) was a postulate of experience rather than thought ... No man who hears the roar of the lion near him will turn to philosophy to ask whether there is any such objective reality as the lion, and no man who has had an experience of God is concerned to ask whether the philosopher will allow him to believe in God. Where we find atheism in the Old Testament it is a practical rather than theoretical atheism ...

(Rowley 1956:48-49)

The notion that natural (a)theology is alien to the Hebrew Bible has been accepted uncritically in philosophy of religion as well; many assume that no such thing exists in the Hebrew Bible. In popular stereotypes, it is taken for granted that there were radical ontological and epistemological differences between Israelite religion and Greek philosophical theology. Thus according to Allen (2007):

In contrast to Aristotle, the claims made by Genesis and the rest of the Scriptures of ancient Israel do not spring from a desire to discover the principles of nature's operation, nor even account for the existence of the universe. Belief in a Creator is not affirmed by the ancient Israelites because they desire to explain the world's existence and order. Its existence and order do not form the grounds for belief in God. On the contrary, they believed in God's self-revelation, first to Abraham, the founder of their race, and then to the other patriarchs, such as Isaac and Jacob, and then to the prophets. Their belief in the Divine is a response to God's initiative, rather than the result of their investigation of nature's order and origin.

(Allen 2007:3)

This denial of the role of natural theology in ancient Israelite religion is based on a theological, rather than historical, appropriation of the development of ideas in Israelite religion. For example, James Barr (1994) identifies traces of natural theology in the Hebrew Bible when, in his Biblical Faith and Natural Theology, he responded to Karl Barth's The Knowledge of God and the Service of God (1938). Barr argued that theologians who assumed that biblical worldviews were in absolute opposition to the spirit of philosophy were not being descriptive, but under the influence of neo-orthodox dogmatics and the Barthian aversion towards natural theology. Neither did they themselves avoid a philosophical framework seeing that they were motivated by personalism and 'semi-existentialism' (see Barr 1999:168). The belief that biblical theology shuns philosophy completely is only possible for scholars as long as their awareness of their own philosophical assumptions is minimal (Gnuse 2001:3).

By contrast, Barr (1994) showed that historical interpretation and biblical theology are riddled with philosophical assumptions. Natural theology is presupposed in the world behind the text of biblical stories about creation and in the logic behind the laws, prophetic discourse and wisdom. But if that is the case, the question may be asked whether supposed reasons for believing or disbelieving in the existence of deity might not also be implicit in the biblical discourse. Although the text is not philosophy of religion, it does witness to folk-philosophies of religion implicit in the metaphysical assumptions of ancient Israelite religion.

To justify this seemingly outrageous claim, I would like us to consider the phenomenon of 'folkphilosophy'. The concept of folk-philosophy is most prominent in comparative philosophy and world philosophy dealing with ancient and/or non-western cultural worldviews. It refers to the 
taken for granted metaphysical, epistemological, ethical and other assumptions that underlie the worldviews embodied in ordinary language and myth, proverbs and songs. It comes to us in the form of philosophical presuppositions about reality, existence, life, knowledge, truth, belief, morality, etcetera, that went without saying. These presuppositions do not themselves represent conscious critical philosophical reflection by the agents holding them, even though such reflection, whether witting or not, lies in the communal past. In short, all cultures, whether living or dead, western or eastern, philosophical or mythological, have folk-philosophies that are implicit in their ordinary language; ancient Israel is therefore no exception.

But there is more. Folk-philosophies can be accessed via a philosophical analysis of a people's religious literature, regardless of its genres. In other words, working with the relevant data, philosophers engaged in the clarification of the conceptual content of worldviews can derive 'philosophy' from such discourse via a reconstruction of the implicit takenfor-granted worldview(s), as Ninian Smart (2008:7) notes: 'It is possible to extract a world-view from a person's thinking and living, even when he or she is not mainly concerned with presenting a system'

Given the presence of worldviews and natural theology in ancient Israelite religion, we are warranted to speak of folkphilosophies of religion in the Hebrew Bible. Of course, natural theology is not necessarily to be equated with philosophy of religion, as Barr (1994) fully realised:

Something more has to be said to define our theme in relation to two concepts, firstly the philosophy of religion ... the philosophy of religion is not necessarily or absolutely linked with natural theology; for example, one might pursue a philosophical approach to religion while denying natural theology altogether. Nevertheless, it seems that there is a common tendency in the opposite direction; [?] traditional natural theology has provided much interesting matter for the philosophy of religion, for example, traditional arguments for the existence of God. And conversely the denial of natural theology has commonly gone with a strong emphasis on revelation, and this in turn has been taken to mean that there are no adequate resources for a philosophical understanding of God. In extreme cases, the emphasis on revelation has been taken to mean that philosophical discussions of God and of religion have no relevance for Christian faith whatever.

(Barr 1994:3)

Quite so, but technically, natural theology is still a subsection in analytic philosophy of religion dealing with arguments regarding the nature and existence of the gods without recourse to any special or supposedly supernatural revelation. Such arguments need not be explicit or formulated in philosophical format or jargon. In the context of the Hebrew Bible, they will have taken the form of taken-for-granted reasons for believing that Yhwh (and other gods) exists and that certain alleged divine beings are nothing of the sort. It will also include appeals to reason and experience in order to justify certain beliefs about the nature of deity. The question now is as follows: are there examples of non-western folk-philosophical discourse analogous to arguments in contemporary natural theology in the Hebrew Bible? The answer to this article is an unambiguous, albeit qualified, 'yes'. This is in order, but how does one go about demonstrating it in a hermeneutically sound manner?

In the quest for discerning folk-philosophies of Israelite religion, the task of the biblical scholar is analogous to the African ethno-philosopher. It is not our place to argue normatively for or against the existence of God, but rather to look for folkphilosophical reasons that went without saying and which now lie nascent in the biblical discourse. These will inform us as to why the ancient Israelites themselves believed in or doubted the existence and particular nature of gods. Research for this kind of natural theology in biblical theology is therefore minimalist, descriptive and historical and not a systematic, evaluative and normative endeavour. In short, philosophy of religion is combined with the history of religion.

\section{FOLK-PHILOSOPHICAL ARGUMENTS}

\section{IN ANCIENT ISRAELITE RELIGION}

\section{REGARDING THE NATURE AND EXISTENCE OF DEITY}

While most biblical theologians deny that the Hebrew Bible contains arguments for the existence of Yhwh, a few exceptions can be found. To be sure, these exceptions are not necessarily descriptive and historical in orientation. For example, in his discussion of 'The Reality of the Biblical God', Patrick (1981:117134) developed what he considered to be literary versions of three traditional philosophical arguments for the existence of God. Patrick discerned what he thought could be seen as biblical varieties of the ontological argument (supposedly implicit in the suspension of disbelief in reading the story), the cosmological argument (allegedly by rendering the world in the text as true life) and a moral-existential argument (implicit in the way the Hebrew Bible evokes an experience of the holy). Although this is interesting, Patrick's ideas remain on the level of narrative and rhetorical criticism, not philosophical clarification. He is seeking to be theologically relevant at all costs and not merely concerned with historical-philosophical elucidation.

\section{Implicit arguments}

On the level of implicit arguments, I would like the reader to imagine travelling to the biblical world in the text and sitting in on a meeting of the elders at the city gate as a modern western stranger (a philosophical anthropologist, if you will). One's role is indeed like an analytic ordinary language African philosopher as described by Hallen (1996:218-219). With reference to their gods, imagine that we could ask one of these elders 'Why do you believe $\mathrm{x}$ ?' Here, one is looking for a reasoned justification of the sort where they might respond with 'We believe $x$ because $y^{\prime}$ (analogous to what is referred to as 'philosophical sagacity' in African philosophy). Of course, if ' $x$ ' is 'Yhwh exists', then ' $y$ ' might be 'because our fathers taught us Yhwh delivered us with a strong hand from Egypt'. This would amount to an 'argument from tradition' which, while fallacious as an appeal to authority, whether true or not, can be seen as part of the folk-philosophical rhetoric for the justification of a belief. To be sure, it would concern what is alleged to be 'revealed' rather than natural theology. Perhaps one can probe further and ask how they know it is true. Alternatively, one might also try to understand what they mean when they say Yhwh is a living god and how they know this. The responses forthcoming might satisfy neither philosophical nor theological orthodox sensibilities, but this is not required for a descriptive historical clarification of the folkphilosophical arguments in ancient Israelite religion.

\section{Explicit arguments}

There are bits and pieces of residue folk-philosophy of religion explicit in the Hebrew Bible. These appear in what is assumed to be sufficient reasons for certain beliefs regarding the nature and existence of Yhwh and an the obvious place to look is in wisdom motifs. Wisdom motifs are also present in poetry and song. One recognised instance of such quasi-philosophical thinking in the Hebrew Bible comes from the Psalter. Thus, as Davidson (2009:33) recognised, we stumble upon (and over) a section of Psalm 94:7-12, which reads:

and they say, 'The LORD does not see;

the God of Jacob does not perceive.'

Understand, $\mathrm{O}$ dullest of the people;

fools, when will you be wise?

He who planted the ear, does he not hear?

He who formed the eye, does he not see? 
He who disciplines the nations,

he who teaches knowledge to humankind,

does he not chastise?

The LORD knows our thoughts,

that they are but an empty breath.

This text clearly presupposes natural theological reflection as preceding the act of penning of these ideas. How did the author know (or thought he knew) these things without some abstract contemplation regarding the nature of deity? The question now concerns the nature of the reasoning in religious thought encountered in the underlined text. Can it be described in extrabiblical philosophical categories that, though anachronistic are not necessarily distortive of intra-textual conceptual backgrounds? My answer is 'Yes' and in philosophical terms it may be said that the underlined section presupposes what can be called an abductive argument from design. Abduction is a method of logical inference that is pre-scientific. In layman's terms it means having a 'hunch' and to argue from the conclusion to the premises, that is, from the effects to a supposed cause. More formally stated, the Psalm presupposes the validity of allowing the precondition $a$ to be inferred from the consequence $b$.

Of course, the implicit argument behind this natural theology might be faulted for committing the fallacies of presumption, affirming the consequent and anthropomorphism (there are multiple alternative possible explanations for $b$ ). Since the atheological critiques of David Hume, the particular ideas about causality have fallen out of fashion. In addition, it was Kierkegaard who realised that arguments from design (as they are called) already presuppose what they seek to prove. But whether the reasoning presupposed in the world behind the text of the Psalm is invalid or not is not our primary concern. The objective of the biblical scholar should be to describe, clarify and understand, rather than to adjudicate, explain or criticise. Whatever the case, this instance of natural theology (which is surely the tip of the folk-philosophical iceberg in the world behind the text given that the Hebrew Bible's intentions were not philosophical) clearly shatters the stereotype of Israelite thinking as not concerned with inferring the nature of deity via the nature of the natural world. It furthermore confirms the words of Knierim (1995):

Because of limitation of space we can only allude to philosophical science in the Bible. The extent to which philosophy in modern times is acknowledged as scientific, not speculative but based on the empirical disciplines and logic is mirrored in the philosophical nature of many of the biblical texts insofar as it alludes to God in the rationality of thought. What is philosophical thereby depends much more on the kind of thinking, the Geistesbeshäftigung, than on the format, especially when compared with the format of treatises from Greek philosophy on. Even there, the Socratic dialogue was an appropriate philosophical form.

(Knierim 1995:410)

Knierim went further to suggest that Herder's comparisons between Hebrew (biblical) and Greek (philosophical) thought rested on his own philosophical assumptions rooted in the anthropology of romanticism. According to Knierim (1995), what Herder did not realise was that:

.. poetic intuition was by far not the only element in the mentality of the Hebrew literature and that systematization, logic and ration were very much intrinsic to the Hebrew mind, not only embryonically. They were even at work in ... of his beloved Hebrew poetry. The post-Herder evidence forces us to reconceptualise not only our understanding of the Hebrew mind but also the criteria of the philosophy of romanticism for determining authenticity or foreignness.

(Knierim 1995:51)

This insight by Knierim suggests biblical theology should take leave of the Aristotelian dichotomy between philosophy and poetry and Plato's negative assessment of the philosophical value of the latter. Biblical scholars have systematically failed to discern the presence of folk-philosophy of religion in the Hebrew
Bible because they anachronistically assumed that philosophical arguments for the existence of God (i.e. reasons for believing that Yhwh lives) will only count as philosophical if they are found in the form of explicit systematic logical arguments riddled with philosophical jargon. No wonder they concluded no such thing is present in the Hebrew Bible. What this means is that antiphilosophical sentiment in biblical theology is itself not as historical as it thinks but yet another example of sentiments in Barthian systematic theology intruding on biblical scholarship. It is almost anachronistically colonialist in that it only considers certain forms of post-biblical western philosophy to count as philosophy. In this matter, biblical theology would do well to learn from debates analogous to those that raged a generation ago in non-western area studies in philosophy (e.g. African philosophy, see Coetzee \& Roux 2002).

\section{DESCRIPTIVE ATHEOLOGIES IN THE HEBREW BIBLE}

It is an open question whether it is legitimate to speak of atheism in the Hebrew Bible. Research on skepticism found in the Hebrew Bible has already borne this out to some extent (Andersen 1999:225-257; Crenshaw 1980:1-19; Priest 1980:286). However, hitherto the discussion seems to have dried up and no attempt has been made to structure it according to the format of arguments against the existence of deity in analytic philosophy of religion. In the discussion to follow, I shall attempt to do just that.

In research on ancient Israelite religion and the Hebrew Bible, the concept of atheism is considered anachronistic or used only loosely when biblical scholars refer to what they think is 'practical atheism' in some texts (Von Rad 1972:65 and passim). In other words, the phenomenon of radical unbelief (as opposed to skepticism) in ancient Israel has been discussed very haphazardly (even unscientifically) in scholarly literature and it is time to bring some order and quality to the research. For this a historical and comparative philosophy of religion is required and not a biblical theology repeating Barthian slogans.

\section{Atheism and atheology}

The term atheist, in the sense of 'one who denies or disbelieves the existence of God', is first attested from 1571 onwards (cf. Thrower 2000:1). In ancient Greek the adjective atheos, meaning 'godless' or impious, can be traced back to the 6th century BCE when it referred only to impiety, eventually coming to denote a more intentional, active godlessness in the 5th century BCE. By then the term had acquired other meanings, such as 'severing relations with the gods' or 'denying the gods, ungodly' (Martin 2007:1). Atheism, in one form or another, however, predates Greek philosophy with traces found in the east (see Thrower 1980). Biblical theologians discussing atheism have failed to distinguish between the historical varieties of the phenomenon discerned by philosophers of religion working in the context of religious studies. A quick perusal of the Cambridge Companion to Atheism reveals, inter alia, the following subtle distinctions (see Martin 2007):

1. Implicit or negative atheism is the absence of belief in gods with explicit or positive atheism referring to the actual denial of a belief in gods.

2. Under explicit atheism strong atheism is the explicit affirmation that gods do not exist while weak atheism includes all other forms of non-theism, such as the belief that a specific deity does not exist or agnosticism, non-theism, apatheism, but not anti-theism.

3. Narrow atheism concerns particular gods while broad atheism concerns all gods of whatever description.

4. Hard atheism is pro-active confession and promotion of atheism while soft atheism is silent personal disbelief.

5. Theoretical atheism is disbelief which has reasons for denying that god exists while practical or pragmatic atheism involves individuals simply living as if there is no god.

(Martin 2007:1) 
These categories are functional and, although post-biblical, they are no more distortive than other post-biblical descriptive terms (e.g. religion, culture, history, etc., which has no equivalent in biblical Hebrew; see Smith 2004:2). When combining the subtle distinctions in terms of atheism with the fact that biblical theologians have only looked at atheism relative to Yhwh, rather than looking at other deities, the impoverished nature of the discussion in biblical theology becomes clear. We can no longer be satisfied in merely debating whether the nature of atheology in the text is either theoretical or practical atheism. All the other categories in the classification of the varieties of unbelief need to be brought to bear on the discussion Not enough of this kind of in-depth research exists on why the existence of Yhwh and/ or the gods were denied and no one has yet bothered to write a descriptive atheology of the Hebrew Bible.

Beside the concept of atheism, a further term of relevance is atheology. The word makes its first appearance in the 17th century polemical literature, specifically to denote not so much anti-theology or antagonism towards theology, but rather arguments against the existence of God as conceived of in a particular view of deity (Mautner 2000:49). In this regard, the concern today is not as in the past evaluative atheological perspectives on the Hebrew Bible (see Gericke 2004), but rather to offer a purely historical and descriptive account of traces of atheology and atheism in the Hebrew Bible itself. My concern is antagonist discourse in Hebrew Bible that denies the reality of Yhwh in some sense and protagonist polemical denials of the reality of other gods.

\section{Antagonist atheological arguments}

The presence of antagonist atheology in the Psalter is old news. In this regard, virtually all commentaries on the Psalter have noted the denial of god(s) in Psalms 10 and 14 (Psalm 14 is repeated in Psalm 53). In Psalm 10:4, we read:

The wicked, in the pride of his countenance he does not seek

(His thinks:) 'There are no gods'

A similar statement is found in Psalm 14:1:

The fool says in his heart:

There are no gods';

The paraphrase of the Targum Tehillim's rendering of Psalms 14 and its twin 53 tried to downplay the nature of the denial with the following elaborations:

The fool said in his heart, 'There is no rule of God on the earth'. (Psalm 14)

The fool said in his heart, 'There is no God taking retribution'. (Psalm 53)

Many biblical theologians have followed the Targumic reading and have concluded that the Masoretic version presupposes only 'practical atheism'. However, there are several problems with this classification.

Firstly, the classification was wittingly or unwittingly ideologically motivated by the need to deny the presence of natural atheology in the fool's words. This is partly due to allegiance to the popular stereotype of so-called 'Hebrew thought' as articulated by Barr (1966):

The Greek mind is abstract, contemplative, static or harmonic, impersonal; it is dominated by certain distinctions--matter and form, one and many, individual and collective, time and timelessness, appearance and reality. The Hebrew mind is active, concrete, dynamic, intensely personal, formed upon wholeness and not upon distinctions. Thus it is able to rise above, or to escape, the great distinctions which lie across Greek thought. Greek thought is unhistorical, timeless, based on logic and system. Hebrew thought is historical, centred in time and movement, based in life.

(Barr 1966:34)
Despite many biblical-theological discussions during the midtwentieth century that sought to distance Hebrew (biblical) from Greek (philosophical) thinking, these are now known to have been riddled with fallacies such as essentialism, generalisation, stereotyping, oversimplification and caricature (Barr 1966:42). The history of the debate runs from Pedersen (1926-1940), Boman (1960), Barr (1961), Tsevat (1978) to Carasik (2006). Later studies were more interested in showing that Hebrew thought was just as capable of analytical reasoning as Greek philosophy and suggested that the supposed differences in capabilities for abstraction and formalisation were nothing of the sort (Barr 1994; Knierim 1995).

Secondly, the proposition translated from Hebrew into English as 'there is no God' could be read as a generic reference to divinity in general. From a purely linguistic viewpoint we could equally render the Hebrew version as 'There are no gods'. In favour of opting for the latter translation is the fact that the capitalisation of the word for divinity is the default option given the translators' philosophical monotheism and their ideological interests. The translator's monotheism differs from that found in the Psalter in the sense that they are heirs of Aquinas's philosophical theology which denied that God was part of a genus (Aristotelian secondary substance). This stands in direct contrast to ancient Israelite meta-theistic assumptions. There the generic terms for divinity were used with reference to Yhwh to indicate the type of being he was assumed to be even in monotheistic god-talk (see Gericke 2009:20-45). In other words, the Psalter's monotheism still assume the generic sense to denote a genus or species where modern translations to not believe God to be sui generis. The popular classification of the atheology in the fool's words as involving a reference to Yhwh or God makes little sense when the denial is cast in the form of an indefinite description (no god = not a god). Personal names are out of place and it makes little sense to deny there is a god if one was referring to a specific god (but, what about the others?).

Thirdly, we should remember that the atheology of the 'wicked' is not a first-hand account but a polemical caricature. What gives away the game is that the psalmist claims to know what the fools say 'in his heart' (in secret) - the text itself implies that the psalmist had no access to such knowledge. In addition, the fool is depicted as ridiculously oscillating inconsistently between atheism and anti-theism when the existence of the gods is first denied only to be followed by rebellion against quite a specific god (Yhwh). Contrary to popular belief, this is not to be explained as the result of practical atheism, but due to the ideological interest of the author who wants to make the fool appear like an obstinate rebel as opposed to a sincerely disillusioned person. It serves no rhetorical purpose to allow the fool to be recognised as somebody who discovered that the same reasons for not believing in other gods could also be applied to belief in the god of Israel. Thus, the conceptual inconsistencies in the view of the fool in the Psalm (atheism vis-à-vis anti-Yahwism) can be accounted for on ideological-critical grounds with the psalmist projecting his own theistic frame of reference onto the representation of the fool. In combination with ad hominem arguments associating unbelief with immorality, the psalmist could discredit his opponent. This is a universal tendency in religious apologetics to this day: atheists are depicted as willfully obstinate immoral agents rejecting God when, from the latter's point of view, there is nothing to reject.

Fourthly, a bit of deconstruction is in order. By this is meant that another problem with biblical theologians' dismissal of the possibility of theoretical atheism is the fact that the distinction itself in the history of religion proper is recognised not as something absolute. All practice presupposes a minimum amount of theory even if this is subconscious or unarticulated. No one in a religious culture is a practical atheist without what that person consciously or subconsciously believes to be a sufficient reason for being such. Reading between the lines of the descriptions of the wicked, it becomes clear that there are in 
fact reasons for their unbelief. As we shall see, these reasons for unbelief concern arguments related to divine absence and evil.

Fifthly, a more pedantic remark is in order to show the incompleteness of 'practical atheism' as the full classification of what we find in the fool's denial. Aside from the theoretical or practical distinction, commentators will also have to indicate what other formats of atheism is present in the antagonist's atheology. For example, it may be said that, from the description, it would seem that we are dealing with soft and not hard atheism in that the denial is alleged to be private. Moreover, it is positive rather than negative atheism in that the atheology is said to involve the actual denial that gods exist and not merely the absence of belief in gods.

In sum then, it would seem that the popular scholarly classification of the denial of the gods in Psalm 14 as an instance only of 'practical atheism' is both oversimplified and incomplete. The remaining question now is: If the atheism of the fool has some theory presupposed which arguments against the existence of deity were taken for granted? To be sure, it can hardly be expected that the psalmists would give their opponents a platform for their ideas; the psalmists must be inferred from the second-hand caricature. In this regard, it is interesting to note how the Psalmists references to antagonist atheological beliefs are often coupled with charges of the absence of a belief in divine judgment or retribution. Consider the argument against the wicked who deny God in Psalm 94. First there is the reference to the opponent's antagonist atheological perspective in verse 7:

And they say: 'Yah will not see,

neither will the god of Jacob give heed.'

Why did these people believe this? What is it about the world and human experience that offered what was assumed to be sufficient reason for natural atheology? We cannot say for sure, but additional inferences may be drawn from other texts where antagonist atheology is associated with immorality. One such example comes from Psalm 55:20b where we read of people

such as have no changes (keep no law),

and fear no gods.

Consider also the reference to implicit antagonist natural atheological arguments in Psalm 73:10-11 which reads:

... of (what is high) they speak.

They have set their mouth against the heavens,

And they say: 'How does a god know?

And is there knowledge in the Most High?'

From these texts it would seem that there were some people in ancient Israel who thought long and hard about the concept of deity and found certain divine attributes either conceptually incoherent or not the properties thereof not instantiated in alleged divine governance of the world. Note that the scepticism with regard to what Yhwh can know, need not be taken as the antagonist's admittance that there is a god but one which has no knowledge. Once again it might well be a reference to Yhwh, for the sake of the argument, in the sense that atheist philosophers of religion today still speak of God only in the sense of referring to the concept. Whatever the reality behind the caricature of the antagonists views may be, then, perhaps the following hypothetical antagonist atheological arguments might have been operational in the vox populi:

- An implicit argument from divine absence where the failure of any deity to act in certain events seemed to suggest that there is no god.

- An argument from amoral cosmic orders where the fact that evil whether moral or natural seem to befall both the righteous and the wicked (thus an early argument from evil).

In sum then, antagonist atheologies appear to have been motivated by appeals to irreligious experience and conceptual dilemmas in theistic truth claims.

\section{Protagonist atheological arguments}

Another way to discern what arguments against the reality of a god or gods were at least conceivable in ancient Israel is by inference from arguments against the existence of gods foreign to the cult of Yhwh. Surely these could have been applied by antagonists to Yhwh himself. However, by definition, Yahwism's own (protagonist) atheology can never amount to anything more than narrow atheism, that is, the denial of particular conceptions of godhood and not the denial of godhood absolutely. Most of it comes in the form of polemics against idols. Because the texts had no overt philosophical agenda, reasons for disbelief in the reality of other gods are not spelled out. The texts do not present us with extensive discussions of the contents and reasoned arguments. Thus as with antagonist atheologies, the data we have to work with are limited to bits and pieces incidentally encountered in the course of individual psalms whose goals were not themselves atheological.

Apart from the familiar Psalms 58 and 82 where the gods are charged with injustice and their death is proclaimed, several other psalms contain atheological motifs. For example, a wordsearch of Hebrew terms translated 'idols' leads one to a text like Psalm 115:4-7:

Their idols are silver and gold,

the work of men's hands.

They have mouths, but do not speak:

eyes, but do not see.

They have ears, but do not hear:

noses, but do not smell.

They have hands, but do not feel;

feet, but do not walk;

and they do not make a sound in their throat.

Similar references to the gods of the nations as non-living objects are also found in several other psalms with Yahwism's own atheological polemical claims:

For all the gods of the peoples are idols;

but Yhwh made the heavens.

All worshipers of images are put to shame,

who make their boast in worthless idols;

all gods bow down before him.

The idols of the nations are silver and gold, the work of men's hands

These are not just bold assertions. They presuppose a religious epistemology that takes for granted that one can know that other gods are not really gods. Given that ancient Israel came from a world filled with gods and represented a mediocre political entity, we can be sure they did not reach the above atheological conclusions without some serious folk-philosophical reflection. If this is not in the text, it is because the point of the text was not to discuss folk-philosophy but to confess faith. This does not mean that there was no folk-philosophy or that it is invalid for us to attempt to reconstruct it based on inferences from presuppositions. In other words, the absence of explicitly spelledout and systematically formulated atheological arguments here has nothing to do with any supposed practically-orientated Hebraic thinking but merely means that the arguments are taken for granted and presupposed. As such, the atheologies present in the text might to some extent be inferred from what is implicit. What is clear is that in the psalms the denial of the existence of other gods involves a narrow, explicit, positive, theoretical and soft variety of atheism. From texts like those above, we can discern the following implicit protagonist atheological arguments:

- An argument from alleged reification (hypostatisation) charging the nations because of their alleged tendency to treat an abstraction (abstract belief or hypothetical construct) as if it were a concrete, real event or physical entity. In other words, 
it exposes the error of treating as a 'real thing' something which is not a real thing, but merely an idea.

- An argument from the alleged pathetic fallacy where the nations are said to attribute to an inanimate object the characteristics of animate ones.

Yahwistic protagonist atheologies are therefore stereotypically explicit or positive, narrow, strong, hard and theoretical. There is no reason to believe that antagonists could not have applied the same argument to the god of Israel. What is interesting from the above, however, is how in the Psalms, prayers from where many would like to exorcise all philosophical concerns, we find the core data clusters for ontological presupposition reconstruction. To be sure, many of the atheological arguments are nascent, the atheism narrow - yet such ideas would become the staple of atheologies in later deutero-canonical texts like the Letter of Jeremiah (6th chapter) and the Wisdom of Solomon (chapters $12-15)$.

\section{CONCLUSION}

Traces of natural (a)theology are not altogether absent from the Hebrew Bible. Interestingly, the folk-philosophy of religion seems to be best attested in poetic texts involving some or other polemical remark or reflection. These texts do not contain fully formulated arguments for or against the existence of deity but they do provide traces of bits and pieces of implicit folk-philosophies of religion nascent in the presuppositions underlying sufficient reasons for holding to a specific ontological belief in the particular textual tradition. While in the past the biblical theological evasion of this particular locus in analytic philosophy of religion has been popular due to influence from Barthian dogmatics, the prospect of more in-depth research involving a historical and descriptive ethno-philosophical clarification of ancient Israelite religion's own folk natural (a)theologies is now a real live option.

\section{BIBLIOGRAPHY}

Allen, D., 2007, Philosophy for Understanding Theology, John Knox Press, Louisville, Westminster.

Anderson, W.H.U., 1999, 'What is Scepticism and Can It Be Found in The Hebrew Bible?' Scandinavian Journal of the Old Testament: An International Journal of Nordic Theology, 13/2, 225-257.

Barr, J., 1961, The Semantics of Biblical Language, Oxford University Press, London.

Barr, J., 1966, Old and New in Interpretation, SCM Press, London.

Barr, J., 1994, Biblical Faith and Natural Theology, The Gifford lectures for 1991, delivered in the University of Edinburgh, Oxford University Press, Oxford.

Barr, J., 1999, The Concept of Biblical Theology. An Old Testament Perspective, Fortress Press, Philadelphia.

Boman, T., 1960, Hebrew Thought Compared with Greek, transl Jules E Moreau, W.W. Norton, New York.

Carasik, M., 2006, Theologies of The Mind In Biblical Israel, Studies in Biblical Literature 85, Peter Lang, New York.

Clines, D.J.A., 1995,. Interested Parties: The Ideology of Writers and Readers of the Hebrew Bible, Sheffield Academic Press, SheffielCoetzee, P.H. \& Roux, A.P.J., 2002, Philosophy from Africa - A Text with Readings, 2nd edn., Oxford University Press, Cape Town.
Crenshaw, J.L., 1980, 'The Birth of Skepticism in Ancient Israel,' in Divine Helmsman: Studies on God's Control of Human Events, Presented to Lou H. Silberman, James L. Crenshaw, and Samuel Sandmel (eds.), pp. 1-19, KTAV, New York.

Davidson, A.B., 1904, Theology of the Old Testament, T. \& T. Clark, Edinburgh

Gericke, J.W., 2004, Does Yhwh exist? The Case against realism in Old Testament theology, Unpublished PhD Thesis, Depart. of Old Testament Studies, University of Pretoria, South Africa.

Gericke, J.W., 2009, 'What is an אל? A Philosophical Analysis of The Concept of Generic Godhood in The Hebrew Bible', Old Testament Essays 22/1, 20-45.

Gnuse, R., 1980, The Critic of Biblical Theologians: A Review of James Barr's The Concept of Biblical Theology: An Old Testament Perspective - Book Review, BTB (Summer, 2001), viewed from http://findarticles.com/p/articles/mi_m0LAL/is_2_31/ ai_94332330/pg_3/

Hallen, B., 1996, 'Analytic Philosophy and Traditional Thought: A Critique of Robert Horton', in P. English \& M.K. Kalumba, African Philosophy: A Classical Approach, n.p., Prentice Hall International, London.

Edmund J., 1958, Theology of the Old Testament, transl. A. Heathcote \& P.J. Allcock, Hodder \& Stoughton, London.

Knierim, R.P., 1995, The Task of Old Testament Theology - Method and Cases, William B. Eerdmans, Cambridge.

Köhler, L., 1957, Old Testament Theology, transl. A.S. Todd, James Clark Co. Ltd., Cambridge.

Martin, M., 2007, The Cambridge Companion to Atheism Cambridge University Press, Cambridge.

Mautner, T., 2000, The Penguin Dictionary of Philosophy, Blackwell, London.

Patrick, D., 1982, The Rendering of God in the Old Testament, OBT 10, Fortress Press, Philadelphia.

Patrick, D., 1999, The Rhetoric of Revelation in the Hebrew Bible, OBT 22, Fortress Press, Minneapolis.

Pedersen, J., 1926-40, Israel: It's Life and Culture, volumes 1-IV, Oxford University Press, London.

Preuss, H.D., 1995, Old Testament Theology, transl. Leo G Perdue, John Knox Press, London.

Priest, J.F., 1968, 'Humanism, Skepticism and Pessimism in Ancient Israel', JAAR 36, 311-326.

Rowley, H.H., 1956, The Faith of Israel: Aspects of Old Testament Thought, SCM Press Ltd, London.

Smart, N., 2008. World Philosophies, Routledge, New York

Smith, M., 2004, The Memoirs of God Memoirs of God: History, Memory and Experience of the Divine in Ancient Israel, Fortress Press, Augsburg.

Taylor, J., 1854, The Whole Works of the Right Rev. Jeremy Taylor, Brown, Green \& Longman, London.

Thrower, J., 1980, The Alternative Tradition: Religion and The Rejection of Religion in the Ancient World, Walter de Gruyter, Berlin.

Thrower, J., 2000, Western Atheism: A Short History, Prometheus Books, New York.

Tzevat, M., 1978, An Aspect of Biblical Thought: Deductive Explanation (Hebrew), Shenaton 3, 53-58.

Von Rad, G., 1972, Wisdom in Israel, SCM Press, London. 